\title{
Adaptive Reuse Policy Evaluation at the Old City of Sana'a Yemen
}

\author{
Laila Haidar \\ Lecturer, Department of Art and Design, Faculty of Arts, \\ Sunway University, Malaysia \\ Haider.laila@gmail.com lailak@sunway.edu.my \\ Tel. +601133326610
}

\begin{abstract}
The study evaluates the adaptive reuse policy at the Old City of Sana'a, Yemen. A case study of the Tower Houses and private investors establishing projects such as; Hotel, and Art Gallery with high intervention. The data collection was by i) Structured interview with authorities, ii) On-site observation applied services, iii) literature search of forms, guidelines, previous projects, and reports. In result, few vital gaps in the policy practice between the permit of intervention and practice. Also, stages of intervention lack monitoring and expert's validation.

Additionally, Hotel guidelines inapplicable to the Tower House capacity. Findings will help the authority to upgrade their policy practice and guidelines Keywords: Adaptive Reuse, Policy, Evaluation, the Old City Sana'a -Yemen.

eISSN: 2398-4287 @ 2019. The Authors. Published for AMER ABRA cE-Bs by e-International Publishing House, Ltd., UK. This is an open access article under the CC BYNC-ND license (http://creativecommons.org/licenses/by-nc-nd/4.0). Peer-review under responsibility of AMER (Association of Malaysian Environment-Behaviour Researchers), ABRA (Association of Behavioural Researchers on Asians) and cE-Bs (Centre for Environment-Behaviour Studies), Faculty of Architecture, Planning \& Surveying, Universiti Teknologi MARA, Malaysia. DOI: https://doi.org/10.21834/e-bpj.v4i11.1746
\end{abstract}

\subsection{Introduction}

The preservation of historical cities and buildings involves few authorities, managed in parts, and key players arise from these ownership and management arrangements. The local administration is still an essential representative of all benefits. There is a consensus that decision-making with regards to adaptation is complex (Douglas 2006).

In the context of Yemen, The General Organization of the Preservation of Historical Cities and Antiquities of Yemen (GOPHCY) mainly in charge. It was established since the 1980s, in need to conserve the Old City of Sana'a as a designated a World Heritage Site 1984 by UNESCO. Consequently, conservation policy and guidelines have been established and upgraded throughout the years. Reviewing the adaptive reuse policy and guidelines ACT (2014) for the Tower Houses wither partially or fully has not been permitted. The private investors or owners establish noticeably many projects with high intervention on; the space layout and existing materials (UNESCO 2008, Haider and Talib 2015).

\subsection{Purpose of The Study}

The purpose of the study was to evaluate the adaptive reuse policy practice, through a justification of the gaps that leads to AR by the private investors and owners with high intervention on the Tower Houses interior (UNESCO 2008). The rationale of the case study selection at the Old City of Sana'a estimated around (4145) (UNESCO 2008). Besides, the study zone for this research findings was adaptive reuse to a Hotel, so the guidelines were analysed. Overall, the Tower House at the Old City of Sana'a is a prototype for other regions. Varanda (1981) highlighted that there is similarity in terms of; construction, material, space distribution and design element for the Northern mountain regions towards the West coast and mid areas of Taiz.

\subsection{The Objective of the Study}

eISSN: 2398-4287 @ 2019. The Authors. Published for AMER ABRA cE-Bs by e-International Publishing House, Ltd., UK. This is an open access article under the CC BYNC-ND license (http://creativecommons.org/licenses/by-nc-nd/4.0). Peer-review under responsibility of AMER (Association of Malaysian Environment-Behaviour Researchers), ABRA (Association of Behavioural Researchers on Asians) and cE-Bs (Centre for Environment-Behaviour Studies), Faculty of Architecture, Planning \& Surveying, Universiti Teknologi MARA, Malaysia. DOI: https://doi.org/10.21834/e-bpj.v4i11.1746 
In relation to the purpose, the objectives are; to classify the authority in charge with their degree of involvement. To examine the authorization forms in practice by GOPHCY with the conservation process and international standards, to compare the existing Hotels components with the requirements guidelines for the permit practice by MT.

\subsection{Literature Review}

Adaptive reuse identified as a process that can significantly improve the financial, environmental and social performance of the existing built assets; it is well described as "a process that changes a disused or ineffective item into a new function that can be used for a different purpose "(Langston and Shen 2007, Wilkinson, James et al. 2009, Aydin 2010, Chua and Deguchi 2011, Love and Bullen 2011, Kalaci and Dervishi 2014).

The local authority restrains the practice of adaptive reuse since early establishment of the conservation legislation in 1984s, through few constitutional ACTs. As in the (Article 5-10) issued in (2001), stated "creating new openings as commercial or non-commercial reuse are not allowed, Article 5-11 prohibits any change of building usage without legal permission from the GOPHCY. The recent ACT issued in (2014) that addressed the Tower Houses conservation to be preserved mainly from the exterior façade as its the city's authentic image, for internal modifications for private owners allowed in the condition not to modify the original structure. However, this does not allow changes to the function of the space whereby it remains residential.

Nevertheless, the private investors or owners to establish few projects with a permit of practice from other authority such as; Ministry of Tourism MT (Haider and Talib 2015). Basti (2000), highlighted the gap in the local authority practice, as there is considerable duplication of responsibilities and duties among the administrative units and the executive agencies. There is a gap in the previous literature, as it did not discuss the AR policy and guidelines of the Tower Houses in the Old City of Sana'a.

\subsection{Methodology}

\subsection{Study Area}

This study area identified as Zone B at East Surar; it is a route starts from the main road to the old market (Souq), composed of few quarters; Al-Quzali, Alkharaz, Talha, and Daoud, as illustrated in Figure 1. From this area, the case studies were further examined. Other quarters were examined in previous studies (Haider and Talib 2013, Haider and Talib 2015)

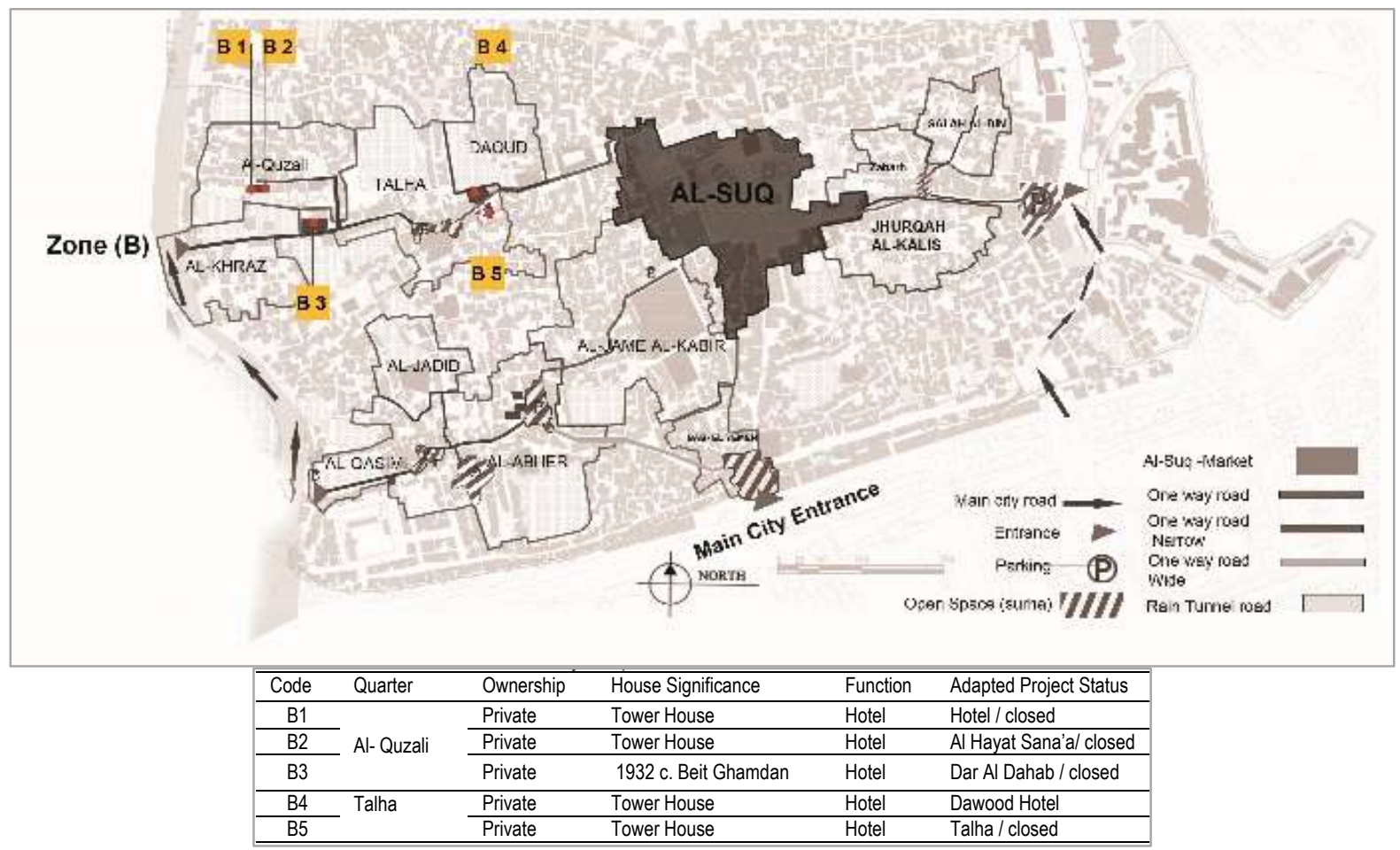

Fig 1. Mapping Location of the Fully Adapted Tower Houses

\subsection{Data collection}

This study data obtained from the authorities in charge of the intervention permits at Sana'a City, such as; sample of previous licenses, inspection forms, reports, and guidelines. Moreover, this study focus on the practice permits from the MT sector, guidelines obtained 
online and previous samples kept for confidentiality matters. Additionally, academic research on the gap in the earlier studies and enhance the study reliability to be a baseline for future work.

\subsection{Data Analysis Procedure}

Based on the international standard guidelines of ICOMOS (1999) and previous studies (Aydin 2010, Chua and Deguchi 2011, Love and Bullen 2011, Kalaci and Dervishi 2014), this study design concept consisted of a; authority degree of involvement, AR process, permits criteria and application for intervention and practice.

\subsubsection{Structured Interview}

The structured interview was conducted face to face with Six governmental agencies; (i) General Organization for The Preservation of the Historic Cities of Yemen (GOPHCY), (ii) Centre for Architectural Research Studies (CATS), (iii) Local Council, (iv) Local Municipality of the Old City of Sana'a, (v) Sector of Ministry of Tourism (MT); (vi) Sector of Ministry of Road and Works (MRW). Additionally, Four relevant specialists in on-site investigators and architects a sum of Ten participants.

The set of questions was designed in reflection to the ICOMOS Charter Principles (ICOMOS 2003) and relevant criteria to the Tower Houses, to evaluate ARP about the project timeline (before, during and after) with the following sub-criteria:

i. Before intervention; Licenses; Involvement; Guidelines/ owner guidelines; Building Specialist; Security on Site; On-site inspector, Type of inspections, Type of Documentation;

ii. During intervention; Degree of intervention, Awareness of intervention, Building process stages.

iii. Project completion; Accomplish approval, Quality control and criteria, Guidelines.

The data was analysed the degree of involvement of each authority with the colour code on the project timeline. To identify the gap of the AR policy through a chart flow as illustrated in Figure 2. For the process to obtain; permits, guidelines, on-site inspection, and documentation followed few standards from previous studies and projects (Kincaid 2002, Wilkinson, James et al. 2009, Langston and Lauge-Kristensen 2013)

\subsubsection{On-Site Observation}

On-site investigation of the fully AR Tower Houses location and building components all case studies were mapped and sorted out in Table 1 and 2 than mapped Figure 1. Each external building condition was examined with scale adopted by (UNESCO,2008) as shown in the Table3. Furthermore, the applicability of the MT criteria of practice evaluated through the current case studies components. Additionally, previous studies criteria for adaptation on the physical features (Kincaid 2002, Wilkinson, James et al. 2009).

Table 1 Fully Adapted House at AI- Quzali Quarter Zone B - District Al-Surar East

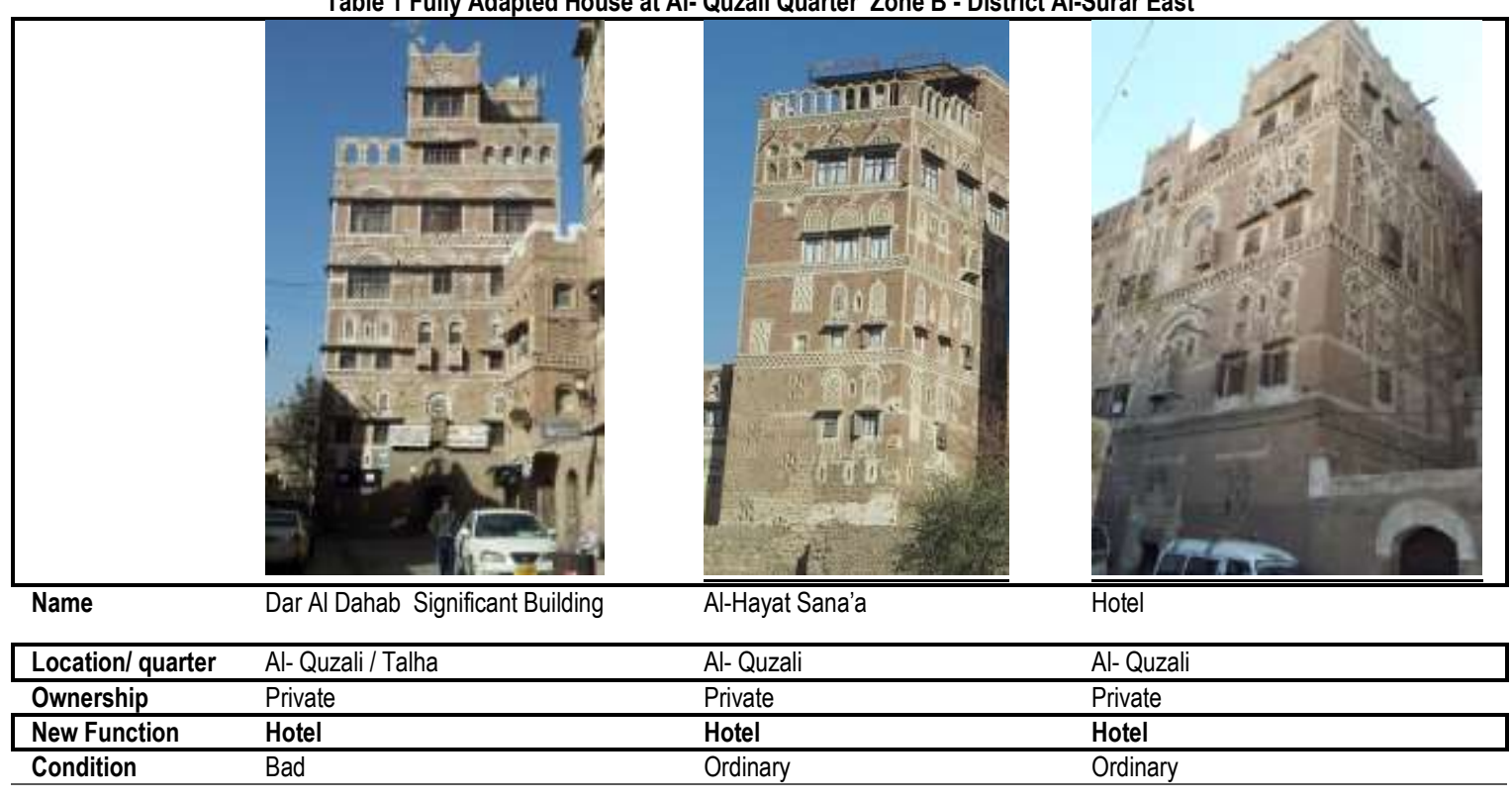


Table 2. Fully Adapted House at Talh Quarter Zone B- District Al-Surar East

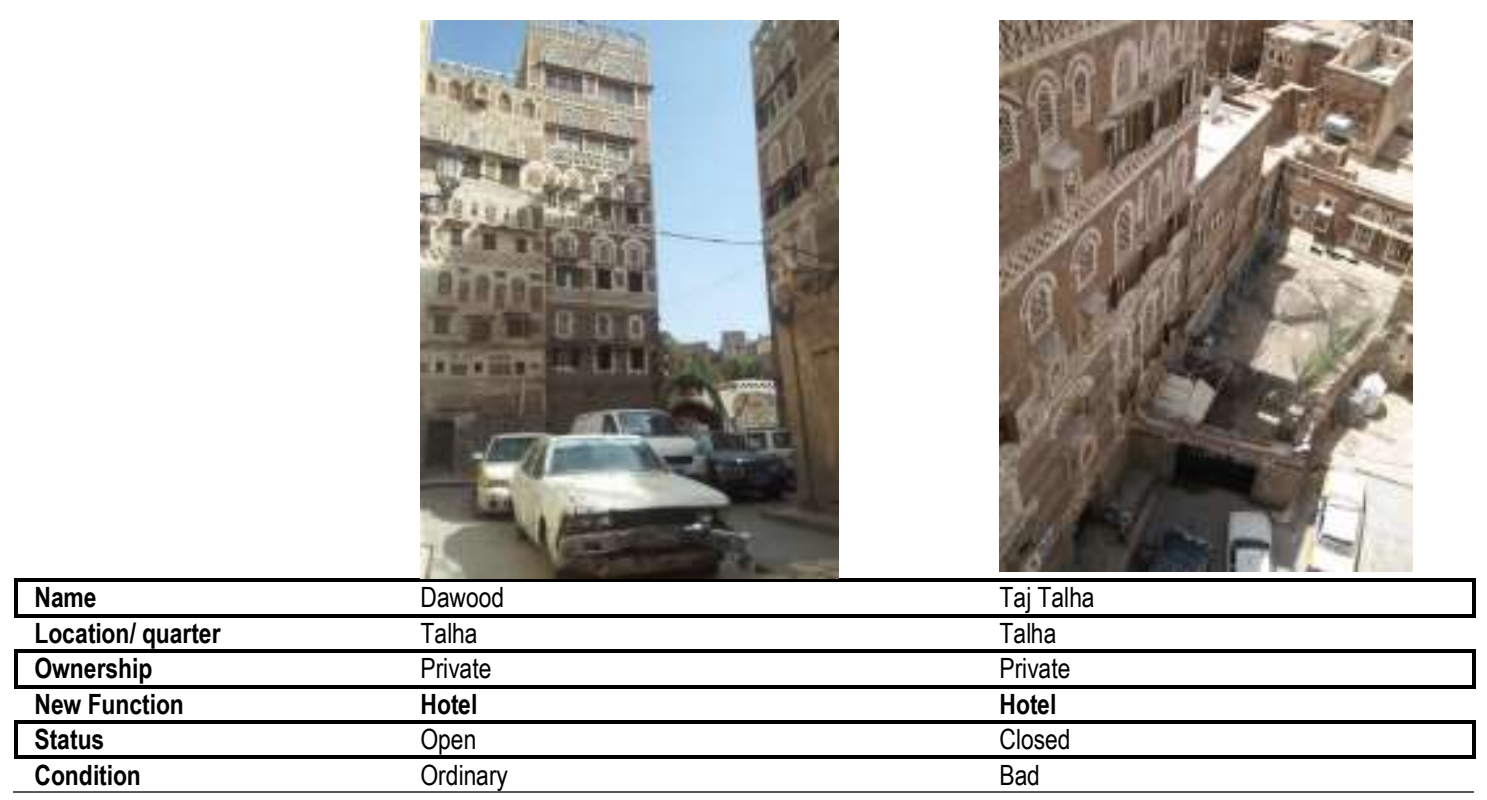

Table 3. Analysis of Building Condition at Zone B

\begin{tabular}{cl} 
Structural Elements & Finishes /Maintenance \\
\hline Available building elements & Good repair / High Level \\
\hline No relevant cracks no risk to stability. & Still efficient /Lacking \\
\hline
\end{tabular}

Show cracks / Represent a risk for stability. No longer safely usable for any purpose.
Entirely lack maintenance and efficiency ruin / Noun

\subsection{Interpretation}

The study revealed few gaps in the authority policy practice that leads to the establishment of AR private projects in the residential area and with high intervention on the interior space to achieve the new space requirements. Finally, the proposed ARP framework illustrated in Figure 5 by the was validated by Ten experts from the authority, decision-makers and scholarly in the field.

\subsection{Findings}

\subsection{Decision Makers and Degree of Involvement}

The intervention permit by GOPHCY involves Five authorisation in sequences per the application as follow:

i. GOPHCY Chairman; All action of conservation and preservation work at the historical cities of Yemen.

ii. GOPHCY Agent Authority; Take action to inform the chairman of the conditions.

iii. GOPHCY General Manager; All on-site investigation and follow up, and reports of the overall building condition.

iv. GOPHCY Authorization Director; Provides all the authorisation and permits of intervention practices.

v. Director of Public Works; Only in case of demolition, dirt removal or coming construction for project management.

These findings sorted with colour code in Table 4, shows the degree of involvement at all stages of the project by; Authority Chairman, General Manager of Inspection and On-site inspectors. Still, for ARP it lacks two authorities were not listed in the intervention permit form; One the MT which provides Permits of Practice for hotel or cultural activity that is common at the Old City of Sana'a. Two is Municipality of Sana'a, it plays a significant role for financial support such as funds, enforce a penalty and sending a force to the site. Then, it should be followed by action force from the Ministry of Road and Work.

Table 4. Authorisation Degree of Involvement in the Intervention Stages

\begin{tabular}{llllll}
\hline & Authority / Sector & Type of Action & Before & During & After \\
\hline 1 & Authority Chairman & Permit Approval & &
\end{tabular}




\begin{tabular}{|c|c|c|c|c|}
\hline \multirow{6}{*}{$\begin{array}{l}\text { Decision } \\
\text { Makers in the } \\
\text { Application }\end{array}$} & 2 & Agent Authority & Permit Approval & \\
\hline & 3 & $\begin{array}{l}\text { General Manager of } \\
\text { Inspection }\end{array}$ & $\begin{array}{l}\text { Permit Approval and assign an on- } \\
\text { site inspector }\end{array}$ & \\
\hline & 4 & Director of Licensing & Permit Approval & \\
\hline & 5 & On-Site Inspector & Follow up and Approval & \\
\hline & 6 & Sector Manager & Permit Approval & \\
\hline & 7 & Office of Public Works & Approval but Not involved & Not involved only Removal Action \\
\hline \multirow{2}{*}{$\begin{array}{l}\text { Not included in } \\
\text { the Application }\end{array}$} & 8 & Municipality of Sana'a & To impose penalties send forces & Only on the action of force \\
\hline & 9 & Ministry of Tourism & Approval of Criteria & \\
\hline Involved & & Not Involved & & \\
\hline
\end{tabular}

\subsection{Adaptive Reuse Process and Policy}

In the result of the ARP process framework emphasise gaps in the project timeline, shown in Figure 2. the essential findings as follow:

i. Lack of coordination among the GOPHCY and MT on the decision making and adaptation criteria for a heritage building. So, investors establish projects without approval from the GOPHCY.

ii. Intervention permit approval at the first stage of intervention, then follow up is neither consistent nor systematic.

iii. Visual inspection is based on the individual experience, and there is not any checklist or guide to standardise the evaluation, all inspection on the exterior only when most of the changes take place on the interior. Moreover, the inspector visits are affected by the owner presences to request certain changes.

iv. Penalty force assigned by the Municipality, yet it's not included in the process for approval nor aware of the penalties. Therefore action will take a while when owners already proceed with the changes.

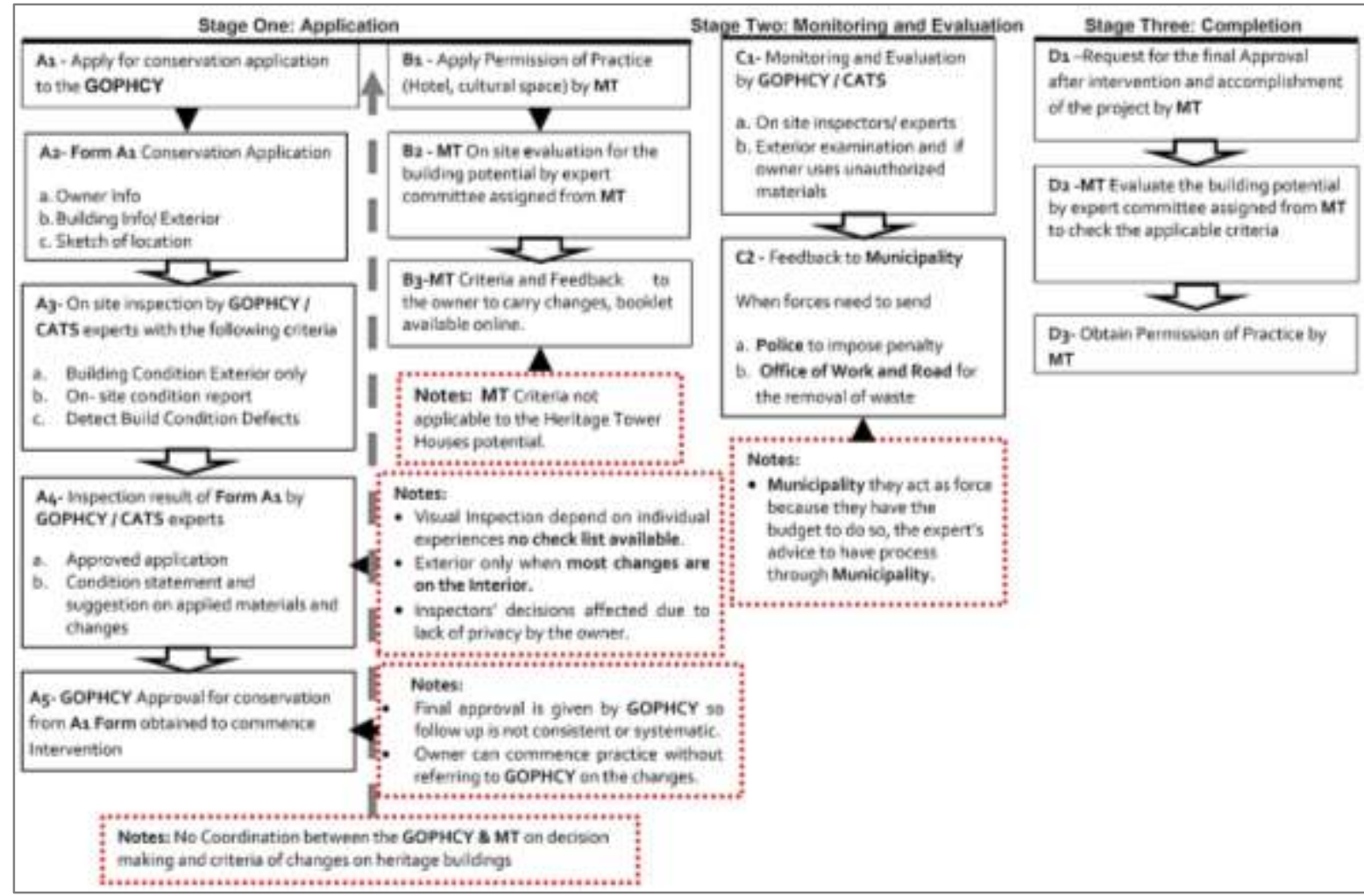

Fig 2. Result of the Current Adaptive Reuse Policy Practice at The Old City of Sana'a Yemen

\subsection{Intervention Permits and Application for Conservation and Adaptive Reuse}

There are Four forms in practice by GOPHCY; wall fencing, notice or removal, rebuild, and restoration. There is not any permit for AR or interior renovation. Besides, conservation guidelines are not provided. In contrary, permit of practice by MT provides a set of criteria for Hotel practice future discussed in section 4.5. The inspection forms composed of three sections;1) location, 2) request for intervention area by floor façade in relation to the exterior façade, 3) authority criteria. Nevertheless, the study examines the consistency of practice through colour code Red for the absence of information, Yellow for lack of evidence, as shown in Figure 3.

As a result, on the; interior inspection, list of common defects, and follow up plan. There is a deficiency in assessments implementation on the forms and documentation, and the inspectors verify it's individual expertise to assess the building. As there is a deficiency of inspection guideline and checklist for building defects. Also, the type of treatment not consistent as most of the feedback explained verbally. Overall, most of the application form lacks detailed drawing with building components and detailed feedback. 


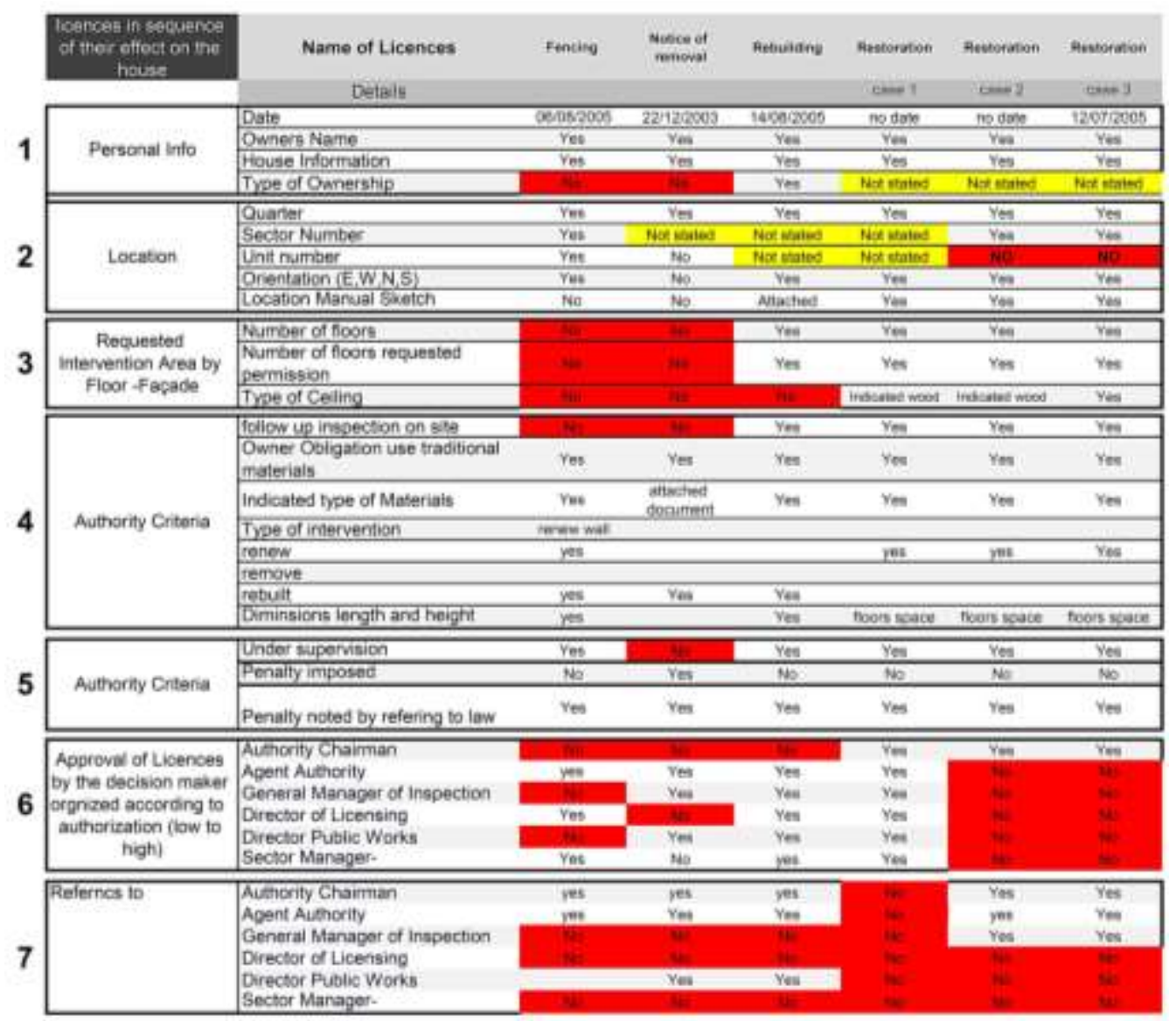

Fig 3. Analyses on the Licenses Consistency of Information by the GOPHCY

Finally, an evaluation of the Authority policy in the context of the international charter, in the similarity of physical features as the Tower Houses at Old City of Sana'a, the study use ICOMOS Charter on the Built Vernacular Heritage (1999) as principles of practice. The charter is composed of four main principles with sub-criteria on each. a Comparison with a checklist for applicability of findings as findings in Table 5.

As a result, proves the lack of research and documentation of practice, especially on the private ownership that applies for licenses, the authority lack documentation of reports, photos, and drawing. Proper documentation prior to the intervention is essential to guarantee minimum intervention and future building defects. Also, organizing the data for research references and follow up. Sitting a force intervention applicable only with the fund, as the authority lack financial resource and don't generate income such as; cultural event. The replacement of materials not applied, there is insufficiency in the; documentation, feedback and reports.

Table 5. Evaluation of the Authority Policy with Principles from the Charter on the Built Vernacular Heritage (ICOMOS 1999)

\begin{tabular}{|c|c|c|}
\hline Principles & Criteria & The Authority Application \\
\hline Research and Documentation & $\begin{array}{r}\text { Any physical } \\
\text { Full Analysis } \\
\text { Form and Structure } \\
\text { Publicly accessible } \\
\end{array}$ & $\begin{array}{l}\text { Exterior-only } \\
\text { Not full - Exterior Façade only } \\
\text { Not Included }\end{array}$ \\
\hline Sitting Interventions & $\begin{array}{r}\text { Landscape } \\
\text { Groups of buildings }\end{array}$ & Not Applied only to funded projects \\
\hline $\begin{array}{l}\text { Traditional Building Systems } \\
\text { Use in Building Guidelines }\end{array}$ & $\begin{array}{r}\text { Traditional building systems and craft skills } \\
\text { Recorded and passed on to new generations } \\
\text { of craftsmen and builders in education and } \\
\text { training }\end{array}$ & $\begin{array}{l}\text { Highlight the use of Traditional material on the } \\
\text { exterior } \\
\text { Some training organised at CATS but no database of } \\
\text { craftsman and builders }\end{array}$ \\
\hline $\begin{array}{r}\text { Replacement of Materials and } \\
\text { Parts }\end{array}$ & $\begin{array}{r}\text { Demands of contemporary } \\
\text { maintain consistency of expression } \\
\text { Appearance, texture, and form throughout the } \\
\text { structure } \\
\text { A consistency of building materials. }\end{array}$ & $\begin{array}{l}\text { No demand for illegal practices } \\
\text { Required but not applied for permission No follow up } \\
\text { Required but not applied for permission No follow up } \\
\text { Required but not applied for permission No follow up }\end{array}$ \\
\hline
\end{tabular}


4.4 Guidelines for Hotel Practice inapplicable for the Tower Houses

The Hotel permit of practice obtained by the MT with a set of guidelines and Ten criteria. The criteria list was compared to the Five case studies operating as a hotel to verify their applicability, as shown in Table 6. As a result, out of Ten the Three criteria applicable to cases were; 1) Residence, 2) Food, and 3) traditional interior. For celebration and social function were applicable for Two; B3) Dar Al Dahab and B4) Dawood, as they have additional outdoor space for; restaurant and rooftop terrace. Overall, the investor should provide service and accommodation for tourists and local customers. However, there are essential criteria to consider is Fire Protection; escape means, brigade access, detection alarms, prevention of the spread of flames, as highlighted in previous studies (Kincaid 2002, Wilkinson, James et al. 2009).

Table 6. Evaluation Criteria by the Ministry of Tourism on the Hotel Case Studies

\begin{tabular}{|c|c|c|}
\hline Type of Criteria & Description of the Criteria Measurement & B2 $\quad$ B3 $\quad$ B4 $\quad$ B5 \\
\hline 1. Residence & $\begin{array}{l}\text { Provide service and accommodation as a home or a temporary residence } \\
\text { and place dedicated }\end{array}$ & \\
\hline 2. Transport & To transport individual or collective for tourists or guests & \\
\hline 3. Food & Food and beverage services & \\
\hline 4. Cruise & Comfort and cruise for tourists and guests & \\
\hline 5. Therapeutic & Therapeutic services - hospital. & \\
\hline 6. Meeting & Services conferences and meetings for businessmen & \\
\hline 7. Social & Celebration and social function & \\
\hline 8. Recreational & Amenities for swimming, sports, and the arts & \\
\hline 9. Banking & Banking facilities and information for guests & \\
\hline 10.Traditional & Heritage Building excepted to maintain traditional interior & \\
\hline
\end{tabular}

\subsection{Discussion}

\subsection{Classification of The Decision Makers for ARP}

The ARP should be legalised by the GOPHCY with a classification of the decision-makers to close the gap of permits between the intervention and practice ones. By including the MT and Municipality in the process and limit the less involved parties. Then flawless ARP will be able to control the degree of intervention.

\subsection{Establishment Forms and Guidelines for Conservation and Adaptive reuse}

An upgrade and establishment of new forms that will include the interior layout, with detailed architectural drawings for the construction proposal showing materials and construction techniques are essential to any conservation project (ICOMOS 1999). All documents submission should contain; pictures, detail drawing CAD for a proper evaluation, corrections, and approvals.

\subsection{Systematic Evaluation for The Building Condition}

A checklist of the common building defects and materials that will facilitate the On-site inspection to be more precise and systematic, with proper documentation of photos. Essentially, it is to ensure isolation of any external pressure by the investors on the final report and decision making.

\subsection{Synchronization the Decision Makers Authorization and Guidelines}

The ARP should ensure synchronization among the various decision-makers by highlighting the relevant decision-makers throughout the project timeline. Consequently, the study proposed the ARP in the illustrated Figure 3 . This chart has been validating from the related authority to ensure the proper practice. Also, the guidelines offered by MT should be suitable to fit with the Tower Houses capacity and physical condition. Essential criteria lack in the MT is to address the fire and safety with official certificates, certificate of hygiene, especially additional services of restaurant or café. 


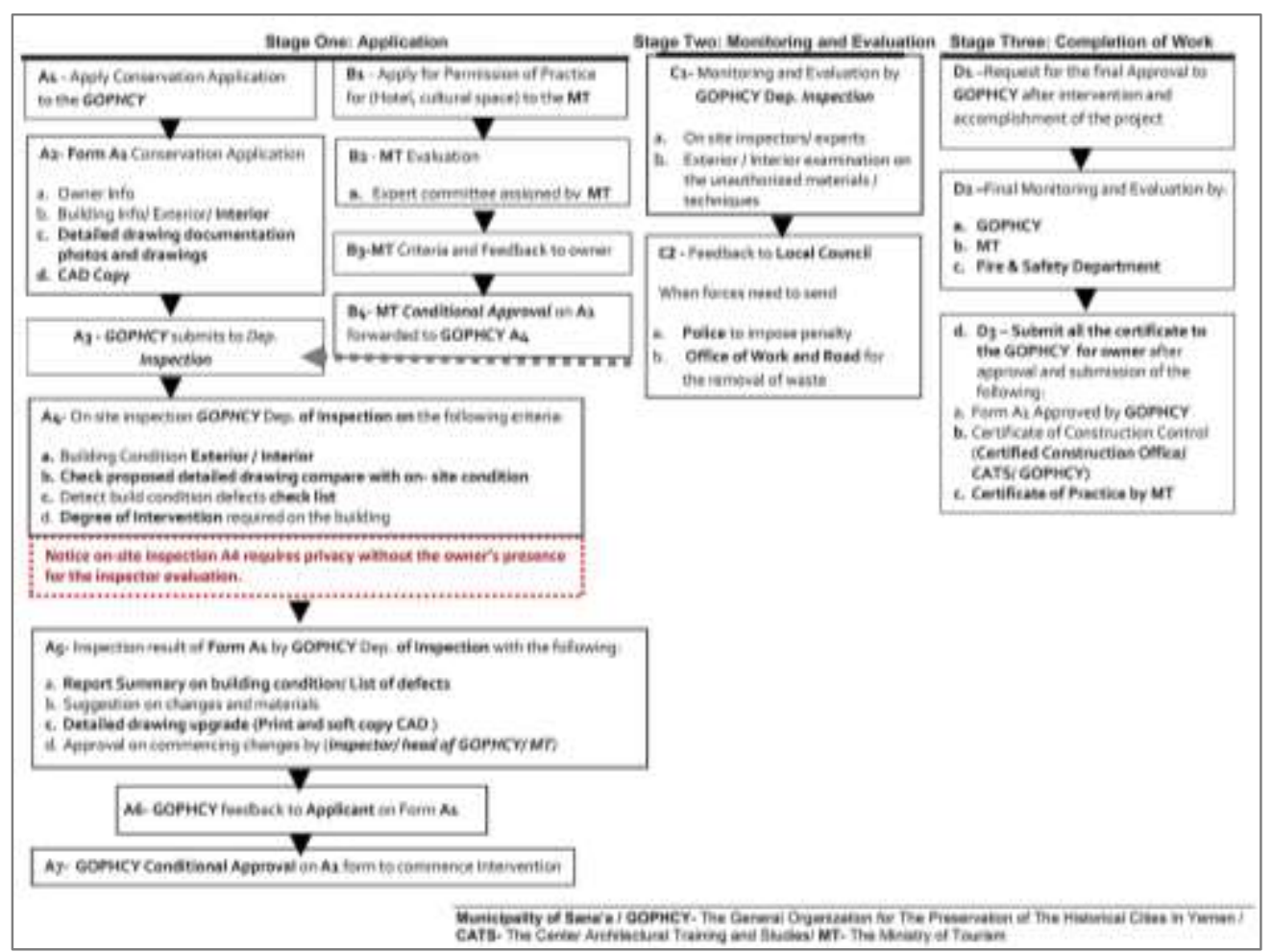

Fig 3. Proposed Adaptive Reuse Policy at the Old City of Sana'a -Yemen

\subsection{Conclusion}

In conclusion, the study recommended enclosing of the adaptive reuse into the authority policy to apply in the process and forms application. The practice permit should be about the building capacity, space layout, technology, and materials. Therefore, these guidelines should be upgraded to fit the Tower Houses physical capacity with the authenticity of traditional elements and materials. The researcher addressed this matter to be through GOPHCY; service requirements should be re-designed by the Ministry of Tourism to suit the heritage building capacity and authenticity.

The set of guidelines will be applicable in other cities around Yemen, as there are similarity in the building components and materials. in general, this practice will reduce the high interventions with guided practice of suitable technology. Heritage building and cities should practice adaptive reuse to keep it revitalised. Therefore, to produce standard criteria and list of defects for the site inspectors, to provide a systematic evaluation of the building condition. Also, a definition of the terminologies the type of intervention. The principles and standards must be in the hands of the public as a guide booklet. Finally, a macro talks with the specialist from GOPHCY, Architects, retired, for an overview on how to upgrade the authority practice with conservation and rehabilitation planner and commit to it.

\section{Acknowledgement}

I want to thank GOPHCY and CATS for the valuable information they contributed to this research. Also, all the experts and corresponded in sharing their ideas and concerns on this study approach.

\section{References}

Aydin, D. (2010). SOCIO-CULTURAL SUSTAINABILITY AND AN ASSESSING MODEL FOR REUSE ADAPTATION. Central Europe towards Sustainable Building, CESB10 Prague.

Basti, A. E., et al. (2000). Sana'a A City Development Strategy. Sana'a Yemen, MOPIC.

Chua, R. S. and A. Deguchi (2011). "Tourist Dependent Adaptive reuse in the old residential quarter of Melaka city. Malayisa." J.Archit. Plann.

Haider, L. and A. Talib (2013). "Adaptive Reuse in the Traditional Neighbourhood of the Old City Sana'a -Yemen." Science Direct: 811-822.

Haider, L. and A. Talib (2015). "Adaptive Reuse Practice in Tower Houses of Old City Sana'a Yemen." Procedia - Social and Behavioral Sciences.

ICOMOS (1999). Charter On The Built Vernacular Heritage Mexico, ICOMOS

ICOMOS (2003). ICOMOS Charter Principles For The Analysis, Conservation And Structural Restoration Of Architectural Heritage. Zimbabwe, ICOMOS. 
Kalaci, E. and S. Dervishi (2014). Implementation Challenges to the Adaptive Reuse of a Heritage Building in Tirana, Albania. Proceedings of the 2nd ICAUD International Conference in Architecture and Urban Design.

Kincaid, D. (2002). Adapting Buildings for Changing Uses. London \& New York, Spon Press.

Langston, C. and R. Lauge-Kristensen (2013). Strategic management of built facilities, Routledge.

Langston, C. and L. Y. Shen (2007). "Application of the adaptive reuse potential model in Hong Kong:A case study of Lui Seng Chun." nternational Journal of Strategic Property Management: 193-207.

Love, P. and P. Bullen (2011). "Adaptive reuse of Heritage Buildings." Emerald Group Publishing Limited 29: 411-421.

UNESCO (2008) The Inventory of the historic city of Sana'a: a tool for urban conservation. UNESCO

Wilkinson, S., et al. (2009). "Delivering sustainability through the adaptive reuse of commercial buildings: the Melbourne CBD challenge." Wilkinson James and Reed.: 1 19 .

Wilkinson, S., et al. (2009). "Using building adaptation to deliver sustainability in Australia." emerald. 